\title{
Contested Community Politics
}

Every night throughout the week, community meetings are taking place across Venezuela: at plazas, in the street, in a basketball court, at the neighborhood corner, at the local school or in whatever space available. Mostly they meet at 7 or 7:30, between dinner time and bed time, but due to people's notorious habit of showing up too late the meeting seldom starts on time. Often they are sitting on plastic chairs, or they are standing in a disorderly circle. More often than not, the majority of the participants at the meeting are women. Sometimes they have a child or a toddler with them. The spokesperson for the executive unit of the communal council will, if present, most often lead the meeting. If not, it will be led by one of the other spokespersons, or the person with the most informal authority.

What the meeting is about varies widely. Sometimes it is a citizen assembly, where the whole community is urged to show up because some important information has to be discussed, elections have to be invoked or binding decisions have to be made. The meeting is normally announced with hand-written posters around the neighborhood a few days ahead. The poster usually lists the time, place and agenda for the meeting, and ends with the word asiste! (attend!) followed by various exclamation points.

Sometimes it is just a meeting for the spokespersons in the communal council. The topics of the meetings depend on what stage of the work they are on. It can be that they are recently elected and have to register with the 
state institution Fundacomunal in order to be legally constituted. Perhaps they are having trouble opening a new bank account. Perhaps they have just received the message from a state institution that their project for fixing the pavement or for repairing houses has been approved. Or perhaps they are having problems with the state institution in getting their project approved.

Sometimes the voceros will have some kind of conflict with other members of the community, and fights will erupt. Sometimes practically no one shows up and the voceros that are present will be frustrated with the apathy that their fellow neighbors demonstrate. Sometimes there will be political discussions, but more often than not, the practical challenges are the most important. Often one or more of the voceros have spoken with someone in a state institution or assisted a seminar, forum or workshop, passing on whatever information they got. Sometimes there will be a representative from the state institution present to give them some information and answer questions. Sometimes the atmosphere will be tense and quarrels will erupt, or there will be optimism and hope. During the meeting, people will play with their mobile phones, smoke a cigarette and smaller discussions will frequently start within a smaller group until someone yells "one discussion, one discussion!" Sometimes it seems as if the meeting will never end and that the discussions will just go on and on. And then, suddenly the meeting is over, time and place for next meeting is agreed upon and most people rush home, while some stay behind and talk in small groups.

Seen from a bird's-eye view, "social change" or "political struggle" or "social policy reform" often remain abstract concepts, because we are unable to fathom the actual real-life dynamics that shape the unfolding of events. In the case of Venezuela, radical social policy reform took place in parallel with the formation of new modes of grassroots organization and grassroots involvement in state politics. These multiple processes of change threw up a host of unexpected social and political dynamics that can only properly be understood through a keen ethnographic attention to detail. To that end, I will focus on one particular case in this chapter, which concerns grassroots mobilization for the building of a state hospital in the parish of 23 de Enero. Through this case, I hope to reveal two important dimensions of popular politics and state-grassroots interaction during the Bolivarian process. Firstly, I will show the complexities 
and nuances that circumscribe ideas and practices constitutive of "community," or "grassroots mobilization." Indeed, it will become clear that barrio communities are heterogeneous social landscapes composed by a diversity of differently positioned social actors, different social identities, networks and organizational formations. If we get a proper grasp on these complexities, we are better equipped to understand not only the richness of grassroots mobilization that evolved during the Bolivarian process, but also the inherent challenges of rolling out social policy reforms through bottom-up participation. Moreover, as a second point, the case illustrates the opaque dynamics characterizing the Venezuelan state and bureaucracy, and the multiple strategies deployed by people in popular sector communities to make it more responsive. Seen together, this case provides a solid platform for our continuous explorations in subsequent chapters into how the Venezuelan state was sought transformed both from the inside and from below, and the numerous challenges and contradictions that this process implied.

\section{UNDERSTANDING “COMMUNITY”}

Within the Bolivarian political discourse, la communidad (the community) became a key idiom through which popular sector neighborhoods and social movements constituted themselves as collective political subjects, as well as the idiom through which local conflicts and differences were negotiated. Vested with particular rights and responsibilities as well as certain social attributes, the concept of la communidad became a potent signifier in both political and everyday discourse reflecting the legitimization of "the local" as a sovereign space and of el pueblo as a political community. Simultaneously, "the community" was constituted as the legitimate recipient for the redistribution of oil wealth through collective consumption. Rather than individual "drops of oil," social welfare, and hence social justice, had to come about through "collective solutions to collective problems," as one activist worded it.

"The community," in its various forms of organization, was also ideologically defined as the legitimate representation of popular interests and agencies in the eyes of the state. This view was constantly reinforced in political discourse, and supported by a range of legislations, resource allocations, policies and reforms aimed at increasing popular sector welfare through state-community co-operation. The role of the state was to support community initiatives based on the notions of soberania popular (popular sovereignty) and el poder constituyente (constitutive power) as 
provided for in the constitution (see Valencia 2015:56-63 for a thorough analysis of the institutionalization of popular power).

The struggle for a new political model of inclusive citizenship is, in Bolivarian discourse, coined as una democracia participativa and protagónica. While the first part of the expression is easily translated to "participatory democracy," the word protagónica (henceforth, protagonic) needs some clarification. It refers to a citizen's right not only to participate in pre-established frameworks designed from above, but also to be a real actor taking the initiative and lead in public affairs. This signalizes a qualitative difference from "only" participatory politics.

A participatory and protagonic democracy was often contraposed to a representative democracy, which was cast as a limited form of democracy reducing participation to the act of voting. For example, in a 1999 speech, addressing a constitutional referendum, Chávez said: "[ la democracia participativa and protagonica] is the restoration of democracy, but a real democracy, the participatory democracy, the democracy which consults" (Aponte Moreno 2008:19, author's translation from Spanish).

Participatory and protagonic are terms which were embraced by people, being a source of pride and evidence of the process of democratic deepening that Venezuela was undertaking. However, participation was not only conceptualized as inclusion in the spheres of formal politics. Rather, it was conceived of as a new mode of citizenship that implied taking an active and conscious role in all ambits of society. This is for example how Vanessa, a housewife and member of a communal council in Propatria, explained it:

Our constitution, approved by referendum, I think it is one of the first ones in the world which is made by the people and for the people, it indicates that this is a protagonic process ... participatory and protagonic. So we the Venezuelans have understood that participation and being a protagonist is part of each of us, I protagonize when I study and can bring this knowledge with me to my community, when I can change my way of being and be a different person. I am a protagonist when I change my family, because I am raising new men and women for society...

Protagonism within the Bolivarian space is thus conceptualized as a way of enacting citizenship through "a bundle of practices" (Lazar 2008:259) that cross-cut both the personal and the political as well as the individual and the collective. 


\section{The Missions}

Popular participation in the context of the Bolivarian process has gone through various stages. As we learned in Chap. 3, Venezuela has a rich history of autonomous grassroots movements that also played a crucial role in the Chávez era. But the Chávez government also fomented new forms of organizations that were situated, to various degrees, in the interface between the state and the grassroots through focusing on social welfare and political empowerment. The coup against Chávez in 2002 and the oil sabotage in $2002 / 2003$ proved to be watershed moment in this respect. After the sabotage was defeated in early 2003 , the economy was in ruins, poverty rates had risen drastically as a result of the strike and Chávez was dropping in the polls. Shortly thereafter, the so-called misiones sociales (social missions) were launched-a series of poverty alleviation and social welfare programs that would be financed by PDVSA and government funds (see D'Elia and Cabezas 2008; Hawkins et al. 2011). In many ways this marked a new era in Chávez's government. Both the government and its grassroots supporters had become radicalized following the coup and now viewed the way forward as moving toward two objectives: advancing the Bolivarian project, and forging a union against the sectors that had sought to remove the government.

In order to bypass the notoriously corrupt and inefficient bureaucratic state structures, the social missions were implemented with the direct collaboration of popular sector groups, PDVSA, local governments, military personnel, special administrators linked to the presidency, and a host of Cuban advisors and technicians. In 2003, Chávez and Fidel Castro struck a deal guaranteeing Cuba cheap oil in exchange for the support of Cuban doctors and advisors in setting up the missions in Venezuela (see Brouwer 2011 for a detailed account of this program). Thousands of Cuban doctors traveled to slums and remote countryside areas in Venezuela as part of what was called Misión Barrio Adentro: without doubt the most popular government social program. During phase 1 of the program, the Cuban doctors lived in private homes where they attended to patients and collaborated with local health groups in making home visits and in setting up outreach programs to bring preventive medicine and vaccines to local communities.

Later, the characteristic two-story octagonal health stations were built, with doctors living on the second floor, and patients' visits taking place in the first floor. Under phases 2 and 3 of Mission Barrio Adentro, clinics, 


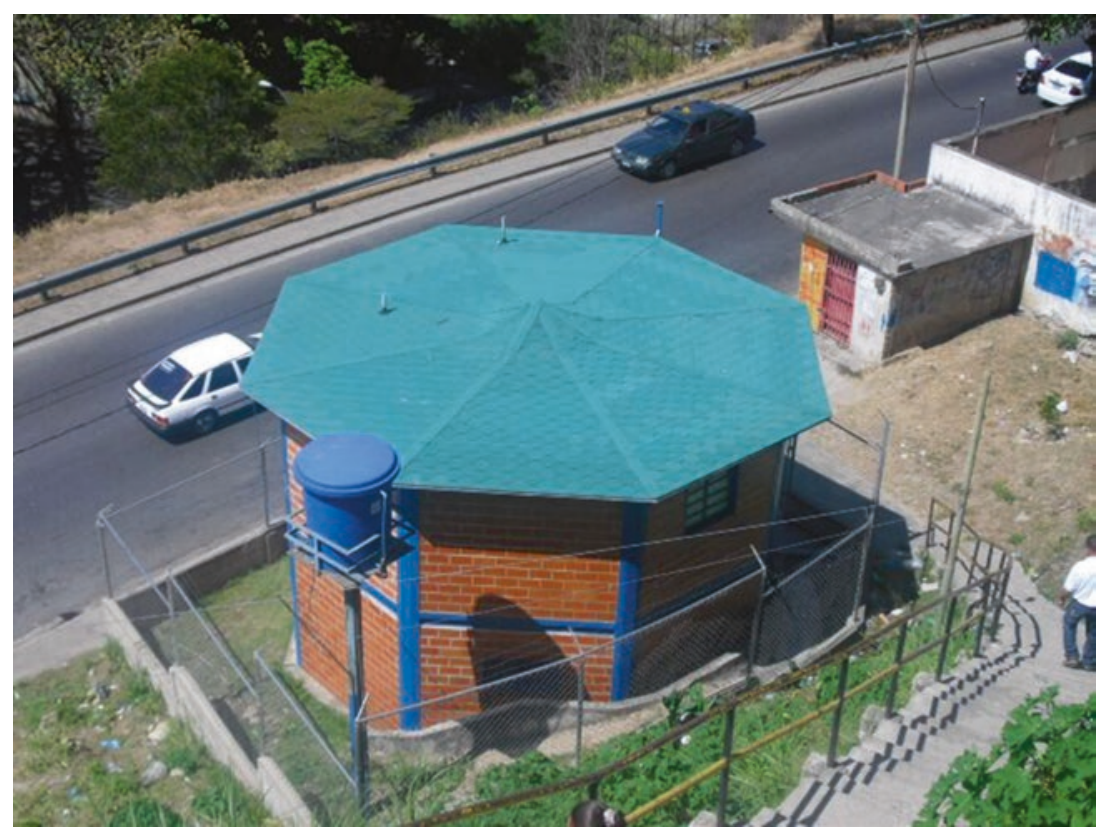

Photo 5.1 A typical module of Barrio Adentro in 23 de Enero. Photo by the author

rehabilitation centers and advanced medical hospitals were built. The health outreach also included dental services (Misión Sonrisa) as well as Misión Milagro, which treated people with eye diseases such as cataract. This was a widespread condition among the poor and elderly who could not afford even routine operations.

The government also set up, with the support of Cuban educators, what are known as the educational missions: Robinson 1 and 2, Ribas and Sucre. Robinson 1 was aimed at teaching illiterates basic reading, writing and math skills, while Robinson 2, Ribas and Sucre were aimed at primary and secondary education, and university-level education. Additionally, community programs for culture and sports were also implemented, as well as Misión Vuelvan Caras - a practical skills training program promoting the formation of co-operatives. Community programs for sports and culture were also organized, notably Misión Cultura. In 2005, Venezuela declared itself to have become a territory free of illiteracy. UNICEF described Misión Barrio Adentro as a "model of comprehensive primary 
health care with active community involvement" (Nichols and Morse 2010:211).

Another highly cherished mission was Misión Mercal, which put in place a government system for the distribution and sale of subsidized food. The political impetus for setting up such a system stemmed from the 2002 to 2003 strike, which showed how food supplies could be used as a political weapon. Small shops and bodegas were set up in rural areas and shantytowns, where basic goods were sold with discounts up to 40 percent. The program also included "soup kitchens" called Casas de Alimentación, staffed by local volunteers who served a full, healthy meal each day to the community's most vulnerable individuals-children, the elderly, the homeless, poor, pregnant women and others who were singled out as particularly vulnerable by the health census carried out by the local Barrio Adentro health committee (see Strønen 2006).

In February 2002, Chávez issued Presidential Decree 1666, which provided the initial legal framework for land titling in barrio settlements. ${ }^{2}$ Through local committees called Comites de Tierra Urbana (Urban Land Committees-CTU), consisting of 100 to 200 families, barrio residents who could prove that they had built their homes themselves could obtain titles for the land they occupied. In some cases, this was state land, and ownership was directly transferred. In other cases, it was private land and the state had to buy it first. This work was co-ordinated by the Oficina Técnica Nacional de la Regulación de Tenencia de Tierra Urbana (National Technical Office for the Regulation of Urban Land Tenure-OTN), an institution that was part of the vice-presidency (García-Guadilla 2007:48). According to government reports, by 2006, there were 6000 CTUs organized across the country, covering about one million families (García-Guadilla 2007:48). Given that about 90 percent of the Venezuelan population was living in urban areas, and around half of it in informal settlements, this was a crucial issue. At the same time, local communities organized themselves in Mesas Tecnicas (technical roundtables), mapping deficiencies and improving local infrastructure related to water, electricity and gas distribution, in co-ordination with relevant state bodies such as Hidrocapital (water utility) and Electricidad de Caracas (electricity). Other forms of organization were the Centros de Participación para la Transformación del Habitat or CPTH (Participation Centers for the Transformation of the Habitat)comprising several CTUs and addressing issues under more than one CTU's responsibility. 


\section{Steep Learning Curve}

These numerous experiences constituted a steep learning curve within popular sector communities. New local leadership figures emerged, and social interaction and cohesion in the barrios increased (see Strønen 2006, 2012). Moreover, it also increasingly socialized the popular sectors into the laws, language and procedures of the state, and created networks between the popular sectors and political figures. Local grassroots networks and electoral committees, organized around election time in support of the government, also added to the proximity between the government and popular sector activists. This became an important reference for the next phase of state-supported popular organization: the communal councils.

The communal councils were institutionalized in 2006 through the Organic Law for the Communal Councils. ${ }^{3}$ The law was revised, also through an extensive popular consultation, and reapproved by the National Assembly in November of 2009. Communal councils are local neighborhood groups, organized around 200 to 400 families in urban areas (significantly less in rural and indigenous areas). They are granted the legal right to plan and implement local social and socio-economic projects as well as projects related to community housing and infrastructure. These projects are funded by the government through various agencies.

A communal council is composed by three administrative committees $^{4}$ and various thematic work committees. The citizen assembly is the maxima instancia de autoridad (highest authority) in the communal councils and composed by all members of the community. All members of the community above the age of 15 have the right to vote, and the elected members of the other committees have to abide by the citizen assembly's decisions. Thus, the community as a whole does not cede power to the elected members of the community councils. In order to highlight this aspect, elected members are not called representatives, but voceros and voceras (spokespeople). The members of the communal council are elected for an electoral cycle of two years. There is also a permanent electoral committee responsible for elections and revocation of mandates.

It is up to the community to decide exactly which working committees they want to form; those suggested by the law are health, education, 


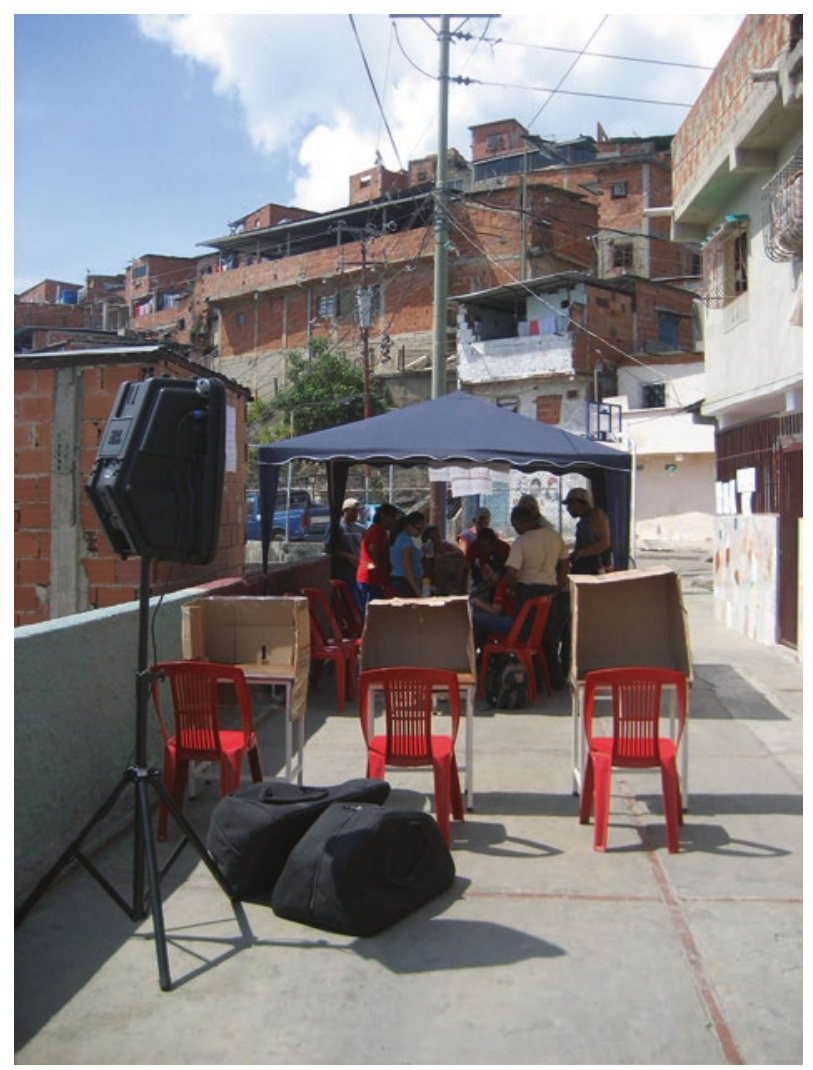

Photo 5.2 Elections in a communal council in 23 de Enero. Photo by the author

housing and habitat, communal economy, security and integrated defense, communitarian alternative media, recreation and sports, alimentation and defense of the consumer, water, energy and gas, social protection of children and adolescents, physical disabilities, education, culture and citizen formation, and finally family and gender equality. The law spells out in detail the electoral procedures, organizational steps and legal requirements that a community has to go through in order to formally constitute itself as a communal council. 


\section{Communal Power}

The communal councils were considered as part of the "Fifth Motor of the Revolution"-communal power-defined as one of the five paths toward the construction of Socialism for the twenty-first century. The contours of the five motors of the revolution were outlined in the Simón Bolívar National Project 2007-2013 (República Bolivariana de Venezuela 2007). ${ }^{5}$ The overarching idea for the five motors was to create political mechanisms superseding and supplanting existing political, legal and territorial structures:

We have to march towards the conformation of a communal state, and the old bourgeois state that is still alive, that is alive and kicking, we have to progressively dismantle it while we go on constructing the communal state, the socialist state, the Bolivarian state. (Hugo Chávez 2007, cited in Aguiar 2007, author's translation from Spanish)

The gradual process of creating the framework for the communal councils in the 2006 law can be read as a radicalization on the government's part of the expansion of popular power as well as a pragmatic assimilation of past experiences. In 2002, the government had passed the Law for Local Councils for Public Planning (Consejos Locales de Planificación Publica or CLPP). The law promoted popular participation in the planning, allocation and execution of public local budgets at the municipality and parish level. In 2005, the government passed the Organic Law for Municipal Public Power (Ley Orgánica del Poder Público Municipal). None of these reforms proved successful in promoting popular participation and mobilization at the grassroots level (Wilpert 2011). People recall that participatory attempts were co-opted or stalled by political figures and brokers at the municipal- and parish level, at the same time as people were getting more experienced in organizing and identifying needs in their immediate communities. This required a new political and legal mechanism that channeled resources directly into what people themselves considered a socio-spatial organizational forum.

\section{The Communal Councils}

Thus, the 2006 Law of the Communal Councils grew out of a gradual process toward searching for organizational and legal frameworks for public participation at the community level. The 1999 constitution has a 
range of references to popular participation, though it does not explicitly mention poder communal (communal power) in its pages (García-Guadilla 2008:8). ${ }^{6}$ However, the constitution explicitly states that citizens have the right to participate in a "direct, semi-direct and indirect manner," including in the "formation, execution and control of public management (gestión pública)" (López Maya 2011:224-225).

The bulk of the resources destined to the communal councils comes from the Intergovernmental Fund for Decentralization (Fondo Intergubernmental para la Decentralización or FIDES) and the Law for Special Economic Allocations derived from Mines and Hydrocarbons (Ley de Asignaciones Económicas Especiales derivadas de Minas e Hidrocarburos or LAEE). Additionally, the communal councils can seek funding from a range of other public bodies, such as parishes, municipalities, ministries and state banks. They can also receive gifts, donations or generate their own income. In 2010, the communal councils received 2.3 billion bolivares for executing community projects. As a term of comparison, municipalities received 2.1 billion for performing their functions (Jaua 2010, cited in Álvarez and GarcíaGuadilla 2011).

Communal councils initially registered with and gained legal status through the Local Presidential Commission for Popular Power (Comisión Local Presidencial del Poder Popular), which was directly appointed by the president. This arrangement received much criticism (López Maya 2011) because it linked the communal councils and the state directly to the executive. Later, this role was passed on to the Ministry of Popular Power for the Commune and Social Protection (Ministerio del Poder Popular para la Comuna y Protección Social). ${ }^{7}$ Fundacomunal, a state institution with sub-offices across the country, is responsible for supervising the organization of the elections, supporting electoral processes and developing projects, as well as distributing resources to the communal councils.

In 2009, the government also introduced the communes"confederations" of several communal councils covering a larger geographical area and with broader legal, financial and administrative rights and responsibilities. In December 2010, the Ley Orgánica de las Comunas (Organic Law for the Communes) was passed by the National Assembly. The communes were presented as the cornerstone of the project to gradually institutionalize popular participation as a new socio-politicaleconomic model. Gradually, they multiplied in numbers and became more 
organizationally consolidated and integrated across the national territory (Ciccariello-Maher 2016), though, just as the communal councils, they are also highly heterogeneous in scope, form and function (see ibid. for details).

\section{SPATIAL AND Social LANDSCAPES}

Ever since I first arrived to Venezuela in 2005 and started to get to know the barrios, it always fascinated me how people seemed to carve out an intimate relationship with their immediate surroundings. Also, I gradually realized how the unfolding of community activism was essentially shaped by spatial and social formations constitutive of popular sector communities. Seen from a distance, the sprawling barrio hillsides look like an impenetrable and homogenous mass. However, from the inside they appear as "a finely differentiated congeries of "micro-locales" (Auyero 2001:93). The barrio contains numerous, sometimes clearly delineated and sometimes partially overlapping, social micro-worlds. Territorialities-both spatially and socially-are inscribed through local histories, limitations in topography and geography, the design of streets, stairways, passages, squares and recreational areas. Each area or zone is imbued with a social identity, forged by the mutual identification between the people living there and their relation to that space. As one man said at a public meeting, describing communal councils: "Territory is not only geographical; it is the territory that we feel."

Barrio sociality and everyday life is radically different from middle- and upper-class lives. Barrios are crowded and over-populated, but also social and informal. Often large chunks of the day are spent in the street, and private space is a luxury, both inside and outside the house. Other people's lives are thrown at you, whether you want it or not. Music, babies screaming and family fights blast out through open windows and doors. Barrio social interaction and street codes are characterized by informality: the ability to crack jokes, to tell stories, to know the fine line between insult and banter, to manage the local slang and to have a generally playful way of speaking, often with a sarcastic undertone. The social code of the barrio is very much characterized by knowing how to manage one's "front stage personality" (Goffman 1956). Stories and information, be it gossip or news, are shared in an almost competitive manner: it is important to show that one "knows," that one is well informed and well connected.

People often have a strong sense of belonging to their barrio and sector. Each barrio and each sector has its own characteristics reflecting 
the history of the barrio and the people who inhabit it. The feeling of belonging is also connected to the sense of personal security and insecurity. Without the option of hiding behind high gates, security guards and cars with tinted windows, personal security is governed through knowing where, when and how to move in the street, and having personal connections to people. Social territorialism is inscribed in the landscape in a number of ways: through "knowing" one's space and place, through a barrio's or a sector's history, through neighborhood associations, through local control exercised by criminal gangs or others popular groups and networks, through sharing certain forms of infrastructure, through natural demarcations such as streets, buildings, hills and so on.

To varying degrees, barrio communities are characterized by tight social networks-for better or worse. The Spanish saying "pueblo chico, infierno grande" [small village, big hell], captures the barrio reality with the constant gossip, conflicts and quarrels. But day-to-day living also allows for developing relationships of reciprocal help and solidarity. Throughout the years, community infrastructures have been developed through collective work. Often-on weekends and holidays in particular-people bring their chairs out in the street or talk with their neighbors in the street corner. Sometimes neighbors look after each other's children, or borrow gas tanks, food or other items. During the 2002-2003 oil strike, when many popular sector neighborhoods experienced food scarcity, many communities started cooking collectively, everyone bringing what they had at home.

\section{Patterns And Processes}

Thus, communities are dense social landscapes shaped over time, and its inhabitants may have friends or foes that go a long way back. On a deeper level, the precariousness of social trust (Ystanes 2011) may often make it difficult for people to forge alliances with the people they do not know, or those that are perceived as different from "my" social micro-world (from the other side of the street, from the buildings "over there," from the barrio "up there"). The difficulties of forging social bonds that can facilitate community cohesion are also important factors for fueling disputes and multiple claims over what the community is and who can rightfully represent it.

At the same time, new strategic alliances and friendships were continuously formed or dissolved within a community. Political and ideological differences, intensified in the polarized political climate, shaped alliances, but did not determine them. People often had radically different 
motivations for taking part in community activism. Whereas some were primarily motivated by hopes of material gains, or by individual aspirations, others viewed activism as a larger political and ideological struggle that should be guided by altruism and work for the common good. As Gledhill notes:

Social action is structured by the pursuit of "interests" by human agents, although the content of those interests is always determined culturally, and may not be "material" or "economic" in the narrow sense. (Gledhill 1994:134)

These diverging perceptions of what community politics were and should be, and the different motivations for participation, were important factors in sharpening the conflictive edges of community politics.

At the same time, local contentious issues were also a part of a larger picture of social and political processes of change. People had differentiated access to wider networks outside the community, to politicians, bureaucrats and public officials, shaping the unfolding of events of internal struggles. Laws, political priorities and institutional processes had direct impact on the life in the communities. Political conjunctures and events could cause community mobilization to stop, to change its focus or to come to a momentary halt.

Thus, community politics are shaped by the intimate and the social, by the intersection of macro-politics coming from above and micro-politics coming from below reshaping local, social and political relations. It is the fluidity of these processes, and the underlying social patterns that sustain and shape them that we need to understand if we want to get a grasp of the real-life dynamics of the unfolding of popular politics during the Chávez era. As Nuijten cites Fredrik Barth on stating: "I am in no way arguing that formal organisation is irrelevant to what is happening-only that formal organization is not what is happening" (Nuijten 2003:157).

\section{The Particularities of 23 de Enero}

The community where the case study that we now will turn to is taking place, 23 de Enero, is quite distinctive from other communities in Caracas (Ciccariello-Maher 2013 for detailed accounts of its history; see also Velasco 2015). As we have previously learned, this parish is histori- 
cally famous for being a hotbed for leftist radicalism. In particular, it is famed for the so-called colectivos (literally, "a collective") whose presence gives the parish a set of particular social, political and spatial dynamics. It is important to note that grassroots organizations calling themselves colectivos are found in a range of popular sector neighborhoods, dedicated to various social, political and cultural activities. However, the particularity of the colectivos in 23 de Enero rests not only in their fame, visibility and organizational strength, but also in their spatial control. Within 23 de Enero, different colectivos are claiming different territories, and the police has not had a formal headquarter in the community for decades. (During Puntifijismo, as we learned in Chap. 4, the local police headquarters was notorious for being a center of police violence.)

The colectivos' presence is highly visible in the community. Their names and slogans appear on murales, wall paintings, often of impressive artistic quality, decorate walls and fences all over 23 de Enero. The murales also feature political slogans, images of deceased revolutionary martyrs or international leftist icons, and political symbols. The most famous colectivos are arguably La Coordinadora Alexis Vive, La Coordinadora Cultural Simón Bolívar, Los Tupamaros and La Piedrita, but there are numerous others with less power and public visibility.

As a rule of thumb, the more powerful and well-established a colectivo's claim over an area is, the safer it is, as "competing claims" for territorial control emerging from criminal gangs and drug vendors are not allowed to escalate. More generally, the 23 de Enero parish is considered one of the safest barrios-if not the safest-in Caracas. Personally, it was within the confines of the territorial areas of the strongest colectivos that I felt the most at ease in Caracas. That being said, their territorial control also comes with a price, and there have at times been a lot of blood spilled in disputes with "enemies" such as drug vendors and delinquents, as well as in rivalries with other colectivos in the area. It is no secret that they are armed, and some of them also cultivate a public image in which arms are very present. This is also part of the reason why the colectivos have a very ambivalent status in the community.

The colectivos are also extensively engaged in social and cultural activities, both on their own accounts and collaborating with the communal councils and other social groups. However, as we will see in the following case study, many residents are wary of their claims to local power, in particular as the communal councils surged as an additional source of formal local authority. 


\section{UNDER SIEGE}

Radical political organization in 23 de Enero dates back to the Pérez Jiménez era and his fall in 1959. The colectivos' later evolution into relatively organized and armed groups came as a response to excessive state violence in the Puntofijo era (see Ciccariello-Maher 2013). In the beginning of the 1980s, 23 de Enero started overflowing with drugs. Several of my interlocutors alleged that this was planned by the government as a means to de-stabilize popular organization in the community. Similar statements have been documented elsewhere (Martinez et al. 2010:274; Ciccariello-Maher 2013:77). To what extent it was a government strategy, is difficult to prove, but what is certain is that lower-level police officers were heavily involved in drug trafficking, cutting deals with, and supplying, local criminals and drug dealers. In any case, the community found itself under siege by both the police and criminal networks. It was the need to respond to these threats that led to the creation of colectivos as distinct, territorially rooted, social organizations. Armed and masked, they would give local delinquents an ultimatum: "Disappear or we will eradicate you." Simultaneously, the police (the Policia Metropolitana in particular who played a crucial part in the 2002 coup and was later dissolved by the Chávez government), famous for its corrupt and violent practices, was a declared enemy.

\section{Ambivalent ReLATIONSHiP}

Among the opposition, as well as in national and international media accounts critical of the Chávez government, the colectivos have frequently been portrayed as armed, violent and dangerous vigilante groups, some also referring to them as the government's paramilitary branch. It is beyond the scope of this book to discuss the "true" nature and correct label of these groups, but many of these accounts have often drawn on hearsay and the invocation of politically charged imageries of the savage mobs and hordes (Duno-Gottberg 2009) discussed in Chap. 3, rather than documented analysis of their actual form and function. However, the colectivos have on various occasions resorted to violent tactics, something which also brought them on collision course with the Chávez government. For example, in February of 2009, a group from the colectivo La Piedrita attacked the headquarters of the opposition TV station Globovision at night with teargas and pamphlets. Their motivation was the perception 
that Globovision had been attempting to incite a coup. The attack provoked a strong response from Chávez who publicly stated that this behavior was no better than the behavior of the far right and that the leader of the group, Valentino Santana, should be arrested.

As Ciccariello-Maher (2013) has shown, the relationship between the government, the colectivos and the Bolivarian process cannot be understood without taking into account their popular genealogy and ideological orientation. For the colectivos, and many popular sector activists more generally, the Bolivarian process in Venezuela is perceived of as the fruit of a long popular struggle. From this perspective, Chávez was by the colectivos perceived of as a catalyst for a broader political struggle, as well as their "maximum leader" (Ciccariello-Maher 2013:5, 84-85). However, they were above all profoundly identified with la lucha popular (the popular struggle)—a struggle that goes far beyond the figure of Chávez.

There is also another important dimension to add, namely that 23 de Enero in general and the colectivos in particular have always been a thorn in the side for the Venezuelan right. Both the colectivos and the so-called Bolivarian Circles were singled out for persecution during the 2002 coup. Allegedly, a list over political activists and community leaders that would be hunted down had been elaborated by the coup mongers, and political persecution of Chavista leadership figures was already well under way when the coup was aborted. As was said at a community meeting in 23 de Enero that I attended: "If Chávez falls, the first place they are going to crush is 23 de Enero." For that reason, the colectivos do see themselves as the armed vanguard for the Bolivarian process should the Venezuelan right try to take over power again with illegitimate means. But so do many other people, whatever name they give themselves or their networks. The colectivos can therefore not be seen in isolation, but as part of the broad heterogenous landscape of popular sector organization and in the context of a long history of struggle from below-including the coup in 2002.

\section{From the General to the Specific}

James Scott has stated that "Any carefully detailed empirical case is always far richer than the generalizations that can be extracted from it" (Nuijten 2003:21). Taking cue from his insight, the rest of the chapter will explore in detail a long process of community mobilization in 23 de Enero that involved colectivos, communal councils and other local community members and activists. The mobilization's aim was to force the government to 
complete the construction of a local hospital, a Centro de Diagnostico Integral (CDI), which is part of the Barrio Adentro mission. The hospital had been abandoned two years prior, just before it was finished, and had been since taken over by rats and drug addicts. In 2009, some people in the community decided to mobilize in order to pressure the government to complete it. Both adjacent colectivos and communal councils got involved, generating a long-term field of interaction (Nuijten 2003) in the form of work groups, activities and meetings between the community and a host of state representatives.

These forms of negotiation revealed how claims of legitimacy, popular sovereignty and power played out vis-à-vis the state. At the same time, an intense mobilization over the politics of local socio-political space was generated: Who would "control" the mobilization? Which interests were at stake? Who had connections to people in high-ranking positions? Who could successfully claim to represent the community? How would "the community" be used as a strategic concept for negotiating internal differences? In short, the case study constitutes the ideal "condensed case" allowing me to capture both the specificities of 23 de Enero and the broader processes characterizing community-led mobilization and the interaction between community and state.

\section{The Story About the Centro de Diagnostico InTegral (CDI)}

The first time I heard about the CDI was at a community meeting in the Christo Rey zone in the spring of 2009. I was invited to attend the meeting by Oscar, a man in his early 50 s who was a member of an "old boys" colectivo in 23 de Enero. They were primarily organizing cultural, social and political activities and differed in that sense from the more publicly visible colectivos which were also concerned with cultivating their image and had a more militant style. However, both Oscar and the other members of the colectivo had lived in 23 de Enero pretty much all their lives and knew a lot of people in the parish.

At the time, I had just arrived in 23 de Enero and had been introduced to Oscar by a friend of a friend. He was a good-tempered man with an internationalist outlook, and was happy to bring me into the parish. The meeting that he brought me to that evening, held in the local primary school, was about the communal councils, and representatives from several state institutions were present. Toward the end of the meeting Oscar 
asked if he could address the crowd with a pressing issue. He spoke passionately about the abandoned CDI, and stressed that the completion of the project would benefit the whole community. The first opportunity to get involved would present itself on the same night of the meeting, he said, in a community assembly by the abandoned building. Oscar and I left by foot for the assembly shortly thereafter. When we arrived a group of 40 to 50 people were gathered outside the locked gate leading into the construction site. No one had the key to the gates, or was able to locate someone who could have provided them. As it was getting late, the meeting was dismissed, and a new one was scheduled for the following weekend.

\section{A Tale of a Stranded Project}

The initials "CDI" stand for Centro de Diagnostic Integral (Center for Integrated Diagnosis). CDIs are part of the Barrio Adentro health system, which was created in 2003 by the Chávez government. The system covered both Barrio Adentro 1, with its octagonal primary health care station, and Barrio Adentro 2, which houses both hospitals (complete with emergency and surgical units) and rehabilitation centers. As previously stated, the Barrio Adentro health system relied on human capital and material supplies from Cuba, based on the oil-for-doctors exchange between Venezuela and Cuba, which was initiated in 2003.

When I started my fieldwork in 23 de Enero in the early spring of 2009, there was only one CDI, located in the F-zone. In addition, there was a rehabilitation center (CDR) in front of the Christo Rey barrio. Behind the rehabilitation center, located between a football and a basketball field, stood what was left of the abandoned CDI building. The only other hospital in the immediate vicinity was Clinica Popular de Catia, located two blocks from Plaza Catia. However, it was a private hospital, which meant that patients either needed health insurance or had to pay for their treatment directly.

Out of all the missiones (social programs) that the Chávez government had launched, the Barrio Adentro system was probably what people appreciated the most. The public healthcare system before Chávez was highly inadequate. Privatization and reduced public spending had relegated the poor sectors of the population to an overcrowded and decaying public health system. Many people died from the lack of access to health care. As there weren't any health stations in the barrios, people had to go to the city center to get treated: an expensive and difficult journey for someone 
living high up on a barrio hillside and perhaps couldn't even afford a bus ticket. If someone needed emergency treatment, they had no guarantee of reaching a hospital or being attended to in time. People told me of family members who had died or nearly died in the waiting room because of inadequate and irreverent treatment. Hospital supplies were often nonexistent or not accessible; one had to have his or her own supplies or buy them from hospital personnel who had stolen them in the first place.

In Venezuela, private health insurances are paid by employers, which mean that the majority of citizens, making a living through the informal or semi-formal sector, were effectively left out of the private health system known as clinicas privadas (private clinics). After Chávez's arrival to power, a larger share of the lower-sector population got health insurance because the possibility to access public sector jobs increased-or because people had a relative that was insured. (It is sometimes possible to extend coverage to the family members of an insured individual.) Yet, many people still depended on the public health system. Having a private health insurance is not necessarily a guarantee of receiving sufficient or adequate treatment. Health insurance plans have coverage limits, and if the insured exhausts that limit, for example, in the case of chronic or longterm illnesses, they are left with no option but to pay out of pocket or to resort to the public system. An important and highly cherished part of the Barrio Adentro health system was thus the Cuba-Venezuelan agreement, whereby people were sent to Cuba for free treatment of complicated, longterm or chronic illnesses. ${ }^{8}$ In terms of primary care, the Barrio Adentro 1 installations have been vital in attending patients in the community that would not have been otherwise able to reach, or afford to go to, a private primary care doctor. The Barrio Adentro 1 system was fundamental in its implementation of vaccinations programs, maternal health outreach, old age and disability outreach, as well as in dispensing medicines that would otherwise be very expensive in private pharmacies. In short, in spite of its shortcomings, the Barrio Adentro system was widely considered the most cherished logro de la revolución (achievement of the revolution).

\section{The Building of The CDI}

CDIs respond to the Ministry of Popular Power for Health (Ministerio del Poder Popular para la Salud), supported by Cuban health professionals working under the vice-ministry (located opposite the presidential palace Miraflores). 
The construction of the CDI in 23 de Enero had started in 2005, through the co-operation of various health committees with the different Barrio Adentro 1 health stations. At the time, the Chávez government was in the process of starting up the Barrio Adentro II phase. The CDIs were the cornerstones of expansion. When this was announced, the local health committees seized the opportunity and made contacts with the Ministry of Popular Power for Health in order to locate a CDI in their area. After long discussions among the co-ordinators of the various health committees in the parish, and in spite of disagreement within the community, it was decided that the only suitable location for the construction of a hospital would be the field where it stands today. It was also decided that the hospital would take over part of the adjacent football and basketball fields.

The building was to be financed by the Instituto Nacional de la Vivienda or INAVI (the National Institute for Housing). The ente ejecutor (building contractor) was Fundación Caracas, or Fundacaracas, which is the property development branch of the Libertador Municipality. Construction work was contracted out to a private company.

The construction process got off to a quick start. However, as Felipe, one of the key community activists involved in the process, later told me, various neighborhood groups soon noticed that things weren't going smoothly.

When the problems started the neighbors over there in the Sierra Maestra sector alerted us, the social groups in the area, that there were problems with the construction of the CDI ... and well, we go over there, we present ourselves, we identify ourselves as the contraloría social (social comptrollership), we talked to the company, we talked to the on-site responsible for the work, and we alerted him to some of the observations that we were making, because there were cracks in the walls, in the roof, the waterproof cover on the floors was deteriorated.

We could see that the job was not done the way it should be, and we started to fight with the head of the company ... we also started to fight with the inspector chief of the work, who we made responsible for the level of deterioration that was taking place. Why? Because he had the obligation to make his observations and report to Fundacaracas so that the work was paralyzed or they sent another company to finish it. So that they could end the contract and we could start up again with another company that was doing the work well ... we had a lot of problems because parts of the population that were living nearby, who had some interests in the CDI, started to attack us. 
Among other serious problems with the construction, I was told at a later meeting when we entered into the building, was the joint compound between the ceramic tiles on the walls, which had a rough, untreated surface. This was illegal for a medical facility, as germs and bacteria could stick to the porous joint compound mass and make it impossible to adequately sterilize an operating room. Felipe told me that, when they later got the project up and running again, they discovered there never was a proper project plan in place. However, at the time, they were simply trying to identify who was responsible and attempting to fully understand what was happening.

We made a number of denouncements, we have copies of a quantity of communication that was sent to people, to Fundacaracas, to INAVI, to many organisms where we are alerting them that the health center is constructed in an erroneous manner ... additionally, it was only two workers for a twostory building, that was insufficient, it would be impossible to inaugurate it in 2007. So we were asking ourselves how is it possible that a center that was supposed to be opened in 2007 had only two people working there.

And well, in the end, within all this pugnacity, there were a lot of problems with those that we think had particular and peculiar interests in this centre. In this case it was the consejal (parish council woman), who was always benefiting from (montada) the health committees, and there was another woman, you met her, who is the señora Yurelia, every time we went there she was confronting us.

On one occasion, we asked her to identify herself, to clarify if o era empresa o era communidad (she was company or community) because she couldn't be both things at the same time ... every time we went to ask the company to show us the accounts, she was confronting us, saying that they were doing a good job, that they were constructing it well, that they had been there that day and just left. We never understood what the interests of that lady were, we really don't understand it still ... to us the important thing is the benefit of the community....

In the end, Fundacaracas and the company made a number of promises, that they were going to finish at the stipulated time. The building was almost 90 percent completed, what was missing were some details and that people from the Cuban mission came and installed the equipment in order to make the center operational. So we retired and thought that we had completed the mission, this was in the beginning of 2008. Our surprise now is that the center is abandoned, we didn't know...

The official explanation, now that the community had taken over the project, was that the project had been abandoned because the construc- 
tion company had run out of money and had to rescind the contract. From Felipe's account, it was clear that there were a lot of "particular interests" surrounding the project, within the community, within the local political office, within Fundacomunal and the construction company. It is quite common in Venezuela for construction projects to stop because of budget limitations, which in reality means that all different interested parties have taken their cut of funds. In this case, the construction company just packed up and left once the community activists were convinced the project would be completed. When the company left the building site, construction was approximately 90 percent completed. But once they left, both the site and the building turned into a dump: stripped of everything of value, its windows smashed, teenagers looking for a place to drink alcohol and do drugs. No one had approached that building until now.

\section{Finding Common Ground with the State}

When I showed up at the following meeting, which took place on a Saturday afternoon, a dozen people were outside the building. Some people from the community had already tidied the area, but rubbish and construction material were still scattered around the site. The CDI was a large, rectangular two-story building of a yellow-orange color, clearly in a state of abandonment. Just behind the building, behind its fence, was a large barrio community. There was a baseball field next to the building, and on the other side a large football field in dire need of maintenance. The octagonal Barrio Adentro health building and the Sala de Rehabilitación Integral or SRI (Center for Integrated Rehabilitation) were located in front of it, next to the street. On the other side of the road, and north of the football field, were two additional large barrio communities.

As I had just started my fieldwork in 23 de Enero, I didn't have a clear idea of "who is who" in the community. However, it was evident that several of those present at the site that day were from the famous colectivos in 23 de Enero. Their militant-like posture and green T-shirts made those belonging to the colectivo La Piedrita particularly easily discernible. As I would soon learn, the presence of the colectivos generated a lot of uneasiness among many community members.

Oscar and Felipe were running around slightly stressed, trying to set up the sound system and microphone that they had brought with them. More and more people were coming, standing in small groups talking, 
and eventually Oscar grabbed the microphone and welcomed everyone. He explained that it had come to their attention, a couple of weeks earlier, that the center was abandoned and dysfunctional, and said that they had contacted other compañeros in order to get the construction process started again. The colectivos had tomado los espacios (taken over the site) two weeks earlier. They had convoked the meeting with the purpose of rescuing this site and converting the abandoned building into a functioning hospital attending the whole of Caracas, he explained. "This is a part of paying the social debt to the poor." Knowing very well that not everyone in the community was happy about the presence of the colectivos, he nipped the criticism in the bud by saying that: "Many have asked themselves what the compañeros from the colectivos are doing there." Some people were nodding. "But," he added rhetorically, "we are all compañeros, and we have all known these sites since we were children, though then we were running across these fields with the police behind us."

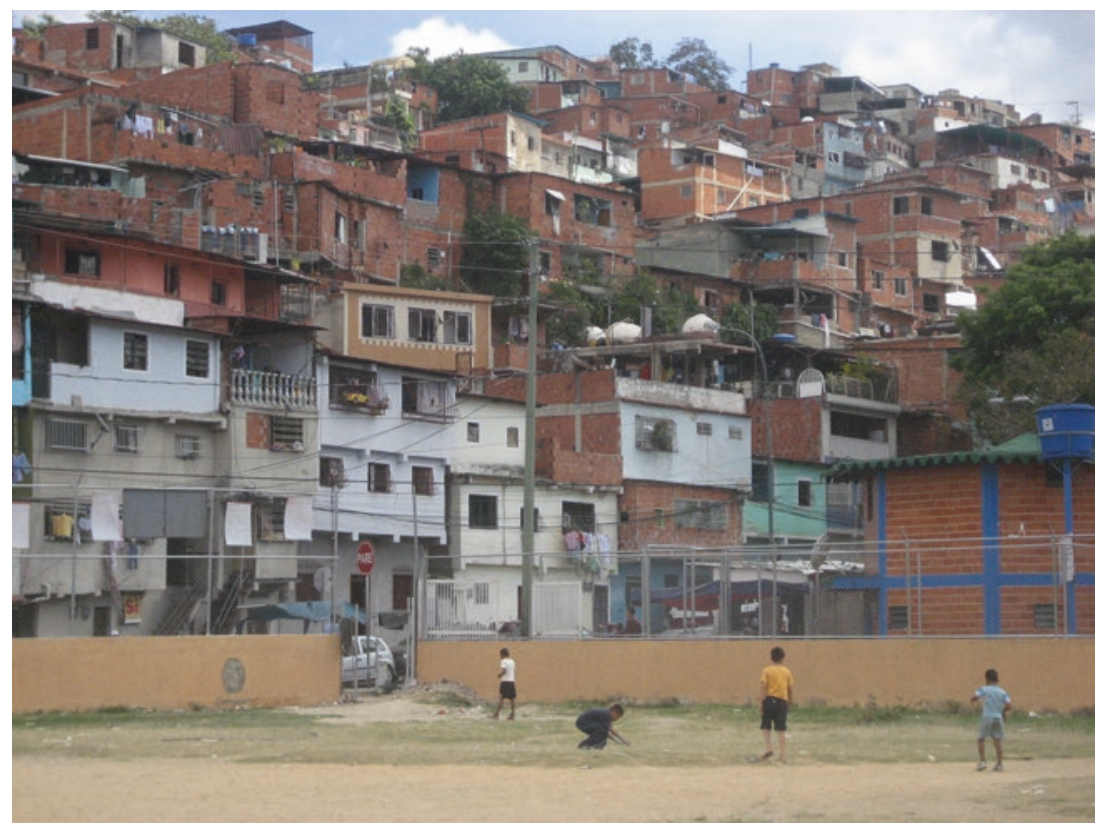

Photo 5.3 A deteriorated football field, a Barrio Adentro module and informal housing constructions in 23 de Enero. Photo by the author 
Oscar had a fascinating personality, never afraid to speak his mind, but always doing it in such a refined manner that he seldom came off as confrontational (even though he clearly was). Like most Venezuelans, he was a gifted speaker. He rhetorically went on to ask who had given the permits to privatize the fields that "some people" were exploiting for their own benefit. By "some people" he meant Señora Yurelia, the woman who had control over the baseball field, and who had come running to the site every time they came to talk to the construction company. I soon learned that she was a key person in the matter of the CDI. She seemed to be a local community "patron," with considerable power for controlling the baseball field. She made money charging baseball teams for using the site for practices and events, as well as selling beer. Additionally, she allegedly had two grown-up sons who could be quite intimidating.

The next speaker was Felipe, who summed up the community's demands: that the project be completed, that the hospital start functioning, that an investigation be launched and that those responsible be prosecuted for corruption "the same way Manuel Rosales should be." With a friendly gesture Felipe waved one of the "officially" invited representatives over-a man from the technical division of Fundacaracas. He was a slender man in his forties, speaking with a soft voice. He made no definite promises, but indicated that Fundacaracas might be able to begin the rehabilitation of the site, while they waited for the new fideicomiso (project commission) to be constituted, led by the Ministry of Popular Power for Health.

The problem was not only the CDI itself, but also the adjacent baseball and football fields. The football field had been used as a parking lot during construction. The weight of the parked trucks had damaged the drainage system beneath the field, and the area was overgrown with weed and grass. Repair and maintenance of the football and baseball fields were part of another project that had also been abandoned. The original budget for repairing the two fields had been modified twice, and the company in charge of the repairs had left before the work was completed. The repairs of the baseball field were about 90 percent complete, while the football field was in worse conditions and only about 70 percent of it had been repaired. The repair company was being fined daily for not completing the work, the public official from Fundacaracas informed. His proposal was that they sit down together (Fundacaracas, the repair company and the community) and form a mesa technica (technical working group) to 
figure out what could be achieved with the remaining project budget. It later transpired that the company had left the project because it had not been paid in time. A change in administrative procedures, involving the merging of two public offices, had caused payments to stop not only for this project but also for other similar projects in Caracas.

The floor was then taken by a representative from the vice-presidency, a chubby man in his late 30 s. His tense body language and uneasy way of speaking suggested that he was not used to being in a barrio or in a community meeting of this kind. After the customary greetings, and after congratulating the community for gathering, he said that the vice-presidency had first been notified about the unfortunate situation with the CDI on Tuesday that week. Once alerted, they had immediately contacted the necessary institutions, ${ }^{10}$ summoning people from the Ministry of Popular Power for Health, Fundacaracas and people from Barrio Adentro. He didn't understand why representatives from the health ministry were not present that day, but hoped

...that the outcome from today is that you elaborate your proposals, everything that you deem necessary, all the necessary complaints, and that a report is elaborated and handed to the minister in charge of the president's office and I will see if it is possible that the report can reach the president ... I cannot promise anything, this is not in my hands, but this is what will be done with today's events.

He concluded his speech by saying that he hoped Fundacaracas would resolve the matter as soon as possible because he was well aware of the importance of the CDI for the community.

The community applauded. Oscar then took the floor again, announcing that it was time for comments and questions from the community. He kindly asked that each speaker limit any comments to two minutes to keep the meeting from going on too long. For the next hour, a number of people took the microphone, some from the colectivos and others from the communal councils.

A man from a nearby communal council expressed his concerns about the safety of the site, and proposed that they arrange a 24-hour surveillance of the area. He was worried about the project being sabotaged, adding that "there are people who do not agree with this, they have personal interests, they have friends that have interests, economic interests, and their families have interests, so this is a problem that affects all of us." $\mathrm{He}$ also urged that the community needed to participate in the supervision and contraloría social of the project once it was up and running again. 
The lack of supervision was what ended the project in the first place, he stated, and it was their responsibility to safeguard it since they knew better than anyone what the problems in the community were.

An elderly woman from another communal council was also asked to speak. She was fumbling at first, but once she got started, she delivered a quite passionate speech, demanding to know the name of the company involved in the project and where it was: "Aha, the CDI was started, what was done, where is the money, it is necessary to look for them, to investigate, who are these people who were given money to do this work and then left it?" she said, visibly upset.

I hadn't noticed, I was sure that this CDI was working, I swore that this CDI was working, how is it possible that the CDI is in such conditions? So much money that the president hands over in order to get things done ... one thing is that it is really necessary, it is for health, it is for us, the community and those who are not from the community as well, because they can come from other parts of Caracas, from Antimano, from Carapita, from Los Frailes, from wherever they come they will be attended to ... we are the ones benefiting from this and how is it possible?

We have to find them, we have to make sure that this is constructed immediately, because that is why the president ... I hear the president talking all the time, I am a true revolutionary, in my heart, if I get nothing from the president I don't care, if they give something to me, fine, and if I don't get anything, fine ... I am 60 years old but I have a lot of grandchildren who are attending school and I have children who are studying, so I want this benefit for them and for those who will come ... so ... we have to fight, as communal councils we have to work on this, it is excellent what is being done here today, and the enterprise has to show up, those who started up all this has to show up, to show their face, to come and say, "look, it was because of this, there wasn't sufficient money, we could not do it, for this reason."

The woman ended her outburst by saying: "I wish that things were done as the president says, but that's difficult, we don't ... I don't know what happens with el pueblo who doesn't want to learn, we have to learn." These words were met with applause from the community and Oscar thanked her for being so passionate about the cause.

One woman, from the communal council located directly behind the building, was upset over the damage suffered by her community since the project had started. Her community had voted against the project when it was first initiated, three years prior, she said. "Well, the project started," she continued, and all of a sudden their houses were invaded by rats "of 
all sizes" and mosquitoes. "Our children are getting sick," she added, and demanded that the authorities fumigate the area.

I want you representatives to tell me a date or that you come and do it immediately ... because we are those who are directly affected, and there are children living there, elderly people, sick people, and we really don't deserve this, because we were those who said that we didn't want this and they did it anyway, so now you have to step up to your responsibilities ... so now I ask the community; in the same way that you supported this, now support us as well ... we are the people who live close to this, you talk about the planned surgical unit, but can you tell me what they will do with all the "things" that they take out from there?

By things, she referred to human waste and used medical material accumulating in a hospital. No other hospital in Caracas was located that close to a residential area, exactly for that reason, she exclaimed. Oscar spoke again, saying that he wanted to respond to the compañera. In a slightly polemic tone, he pointed out that the CDI was a project created to address the lack of access to healthcare that the whole community experienced. As the woman flagged that Oscar was ignoring the infestation problem she had raised, he said, "Well, let's fumigate; this is one of the problems that one has to find solutions to." He then tried to end the session, but a man, who lived nearby, intervened and said that he had lived in front of that field for 34 years and that he remembered that there had been a mosquito problem in the past as well because of a pit in the area. He hoped that the possibility of fumigation would be considered.

A man from one of the colectivos said that he had already heard that "people" were going to hablar paja (talk shit) about the initiative. "There are a lot of interests involved," he warned. "And that is why the project was stopped in the first place. People will talk shit about it to damage the revolutionary process, to damage the health committees, maybe for the purpose of obtaining political privileges," he stated and encouraged everyone present to become spokespeople for their communities, to talk to their neighbors, their friends, their boyfriends, their girlfriends, their children, about the importance of the project.

\section{Contesting the Colectivos}

Another man presented himself as being from the communal council in front of the football stadium, which is the sector that had suffered the leakages caused by the construction work. He said that, two years prior, when 
work on the CDI was about to start and Fundacaracas got involved, he was the only one to oppose the project, along with another man from his sector

because we knew what would happen here, el compañero Jaime and myself, because when Fundacaracas got involved, we knew that the project wouldn't finish, that it was demagogy ... because we were present when they promised that they would not take land from the markings of the football field, and then they took more than two meters. In this football field it isn't possible to make legal tournaments anymore, and there the problem started, because Fundacaracas ... aha, there are the skeletons (of the building), for more than two years it's been like that, and the kids living here cannot play football anymore, they have to go over to the fields in bloque 6 or bloque 37 , and besides, this is a historical site in 23 de Enero.

And the other thing I want to say is that if we are supposed to form work groups, it is necessary to have representatives from the Contraloría General de la República (General Comptroller's office) and from the municipal comptroller because the problem here is the embezzlement of the money from these constructions and in the field ... the problem isn't that these projects have to be finished, we know that they have to, and we will support that, but those who embezzled the money and those responsible within the institutions, like the municipal administration, have to go to jail, and the president of Fundacaracas, the directors, those who gave the orders. They have to go to jail because they misappropriated the money destined to the construction of these projects.

This intervention didn't get the response that one might think that it would, although some nodded. It was quite obvious that everyone knew that the money disappeared was water under the bridge, and that it would be impossible to find out who had taken it. The most pressing issue was now to move the process forward.

It soon became clear that the presence of the colectivos was problematic. A representative from one of the colectivos in the F-zone proposed that they take over the surveillance of the construction site as of the following Monday. The representative mentioned that they had a CDI in their area and that his colectivo had been in charge of security in the area since the CDI was constructed. Another man from a different colectivo intervened. He had a few things to say about the role of the colectivos in safeguarding CDIs. He said:

Look, the satanization of the colectivos has gone so far that many people think that they aren't necessary ... but if the colectivo (name removed) hadn't guarded the other CDI [in zona F], that one might also have been 
in these very conditions ... that is why this is so important and that is why I hope that you appreciate the proposal that the compañero just made, because not everyone offers to be present day and night to guard over a place like this, and we want to say to the community, be on their side, [bring them] a cup of coffee, a glass of water, whatever, so that this work is carried out...

A young girl from the barrio below the hospital then encouraged all communal councils to form an asamblea de seguridad (security assembly) so that the colectivos would not be the only ones in charge of the security issue. Another man, a representative from one of the better-known colectivos in the area, introduced himself and remarked:

Well, good evening to the whole community that is present, to the communal councils, to the colectivos. Well, I am a member of the colectivo (name removed), we have known about the problem here for a long time because we came here to do some meetings with the compañeros living here, but I think selfishness prevails here, we call for unity among all the communal councils, all people who live in this area.

The communal councils and the colectivos are about to start forming the Communes but yet we see that this CDI is in ruins and that the people living nearby have not displayed sufficient will to assume responsibility for addressing the problem. But this situation cannot be allowed to deprive the whole community of 23 de Enero and the whole of Venezuela, because as the compañero was saying previously, this belongs to el pueblo and we are all pueblo. Thus, I, as a representative for my organization, want to underscore for all the compañeros that are present here today that the revolutionary state, together with the colectivos, the communal councils and the whole pueblo of 23 de Enero, should be united in rescuing this CDI. It can't be possible that a collective service is abandoned because of the particular interests of two or three people, we all need our health.

Another thing is that the communal councils and the colectivos, through the commune, should take control over the spaces outside of here, the problems of drug trafficking and alcohol, which are creating the situation we are presented with here. Thus, we, as integrated revolutionaries (revolucionarios integrales), because we have to be integrated, have to assume this responsibility together with the revolutionary state which needs to make itself present here with all the colectivos and the whole of the parish of 23 de Enero. That was all for now. Good night.

The meeting continued for a while longer, with various people chiming in to defend the presence of the colectivos. There were also some discussions 
over whether the football field was actually being used or not. Eventually it was decided that a new meeting would be held the following Monday, and that mesas de trabajo (work groups) would be created to develop a plan with Fundacaracas. The representative from Fundacaracas promised to be present and to co-operate with the community as the process evolved, and assured the involvement of every one present in the institution in the project. The meeting ended with applause and Oscar's parting words:

Well, compañeros, this is the way to walk, hand in hand like Christ says, the revolutionaries are Christians and if we don't share like brothers this will fall apart. We have to move forward, move forward with the diversity and with the unity, if we don't unite we will continue to be poor, if we manage to unite we will achieve satisfaction for all of us. Good night on behalf of all the colectivos, all the communal councils and el pueblo in general that have been present here tonight.

\section{Forging COMmunity}

When I arrived on foot the following Monday, 70 to 80 people were gathered outside the locked gates leading to the hospital site. It turned out that those who had the keys, who seemed to be connected to Señora Yurelia, "the lady with the interests" in the nearby community, had not brought them along. People were upset and Oscar was saying that "we must condemn this; this site belongs to the community." The representative from Fundacomunal was present, and informed everyone that he believed work could start within the following two to three weeks. The groups engaged in a lengthy discussion about when the next meeting would be held, and when they could sit down in work groups. Eventually, they decided that the meeting would take place the following Sunday at $10 \mathrm{am}$. A man then asked if he could read a written statement signed by the spokespeople of various communal councils out loud.

The statement read:

We, the signatories of this letter, spokespersons of the Communal Councils, will let it be known that we do not accept the proposal made on Friday, March 20,2009, by the colectivos to take over the spaces of the CDI, and the spaces for culture and sports. The reasons for this refusal are that 1 ) the actions taken to enter the premises weren't acceptable, as the adjacent communities should have been involved and informed of the steps they were planning on taking; 2) their proposal to guard over the CDI is not agreeable for us as we are against the use of violence and guns. 
The community seems to ignore that 1 ) señora Yurelia is in charge of the baseball stadium area and it was the community that endorsed her role with their signatures; 2) we will also bring to your attention that in this stadium a junior school for baseball has been set up. Apart from what has already been said, the señora Yurelia was elected spokesperson for the sports and recreation committee in (barrio name removed) and it is she who carried out the necessary procedures with the state institutions in order to make these installations work; 3 ) in the football stadium there was a functioning football school, which was coordinated by the señores (name removed) and (name removed) and where children from the communities of (listing up the name of seven different adjacent barrios) were participating; 4) in the Theatre of (name removed), in spite of its deterioration, there are schools of theater, dancing, aerobic and an evangelical church.

Because of what has been said above, we will let it be known that we will accept the collaboration of the governmental institutions, municipality, Ministry of Health, (the presidential office) Miraflores, so that the necessary procedures are put in place to repair the CDI of (name removed) and get it up and running with the help of the community. We rectify that we do not want any colectivo to appropriate the structures that are for the use of the members of the community, in full accordance with the provisions in the article 3 of the Constitution of the Bolivarian Republic of Venezuela. In the city of Caracas, on the twenty-third day of the month of March 2009, representatives of the communities, the following signatures...

Applause followed, and then a lengthy discussion erupted. Various representatives from the colectivos spoke passionately about their disinterested and altruistic engagement in the CDI project, which in their opinion had been abandoned because none of the communities around it had showed any interest. A polemic developed between the colectivos and those who had written the statement referred to above. Tensions continued to rise until a young woman asked to speak. She said she was from the colectivo that was running a radio station from the theater that was mentioned in the letter.

We have been there for around a year, and we can assure and affirm and substantiate to everyone present that before we got there the insecurity in this zone was total, there it was only vandalism reigning, the crime, the delinquency ... and for the community living behind the theater they have to walk between there and Mercal, in fact, people were attacked in Mercal I don't know how many times, and we can affirm and substantiate that since we started to be there no one has been attacked in Mercal again, and we 
have taken care of the security in this space and around it, because many people in the community, when they have problems with the delinquency, who do they go to? To us, and we make sure that they don't consume drugs in the stairways, that they don't rob the school children, their cell phones and backpacks, that they don't attack an old lady who is passing by there, that they don't park stolen cars there or burn cars...

Another man then interjected: “And that people don't amanecen muertos (wake up dead)." The young woman continued:

That they don't ... exactly. Nothing of this has happened since we started to be there and yes, we are a colectivo ... of course we need to maintain security and we defend ourselves like one has to defend oneself against the delinquency, do you understand what I mean? Because you cannot just throw flowers to the delinquents, and we are doing it assuming the risks...

A small conversation erupted in a corner and Oscar asked everyone to keep quiet. The girl then continued:

We are doing it knowing that it may cost us, that we might lose cameradas in the intent but we are doing it anyway and we are not asking the community to confront this, but rather we are doing it ourselves ... and we are not asking for your gratitude, but you should recognize it, I mean, you cannot all the time say that they colectivos are delinquents, that they have arms ... what are we going to do if the communities aren't assuming the responsibility, if they don't have neither the balls nor the ovary to confront the delinquents...

An enthusiastic applause erupted. A man shouted, "That is the way to speak, amiga, that is the way to speak!" The young woman signaled that she hadn't finished:

Another thing: just to clarify that before these meetings here, in January and February 2008, we were in meetings here behind the CDI, with the people from the community here, including the señora Yurelia, and there we prepared some tasks for ourselves, and the community here said that they would be responsible for finding out which company did this and left it like this, that they will make social comptrollership and come back to us and inform us. We let the things pass and, look, it has been a year and we still don't know what the community actually did. 
A man said: "Nothing!" and the woman continued:

So here we are, waiting. So if the community wasn't able to take any responsibility, I am community too, I want to take responsibility for the problems, and well, I am colectivo but I am also community, and as community I am going to assume the responsibility of doing social comptrollership and involve myself in this ... well, finished, that was all I wanted to say...

After this intervention the mood changed notably. One man, from the community that the young woman had criticized, explained what they had actually done, that they had sought answers from the institutions, constantly pestered Fundacaracas to send over their inspectors, but that, at the end of the day, they didn't get proper answers. The crowd acknowledged that they had indeed done something. No more arguments broke out about whether the colectivos were to be involved or not. The meeting ended with an agreement to meet up again for roundtable work on the following Sunday, and Fundacaracas promised to bring tables and chairs.

\section{ROUNDTABLES}

The following Sunday a crowd of around 150 people showed up. Fundacaracas had brought chairs, tables and a large tent, like they promised. Mesas de trabajo (work tables) have become widely used in community work in Venezuela, as well as in public-political meetings where people discuss a new law or other political proposals. This is often called parlamentarismo de la calle (parliamentalism of the street), a term harking back to the pre-Chávez era when people gathered to discuss urgent community issues. On that Sunday, the crowd quickly split into four groups, based on their area of interest: sports, security, social comptrollership and health. Each group elected one person to write down the main points on a large white sheet and one to present the results to the crowd. I joined the group working on social comptrollership. After an hour of group work (Oscar was working hard to stick to the time schedule), the chairs were reorganized so that everyone would be facing the side of the CDI where the presenters would hang the large white paper sheet up and share the conclusions reached by each group. The main findings for each group were the following (Table 5.1): 
Table 5.1 Results from roundtable discussion in the Parish of 23 de Enero, March 2009

The health roundtable

- Develop an overview of the status of the CDI structures

- Evaluate how much time is needed in order to complete the work

- The members of the roundtable are obliged to take measures if they do not get satisfactory answers from the institutions. The measures may be: levantar una acta (make formal written complaints), go to the relevant institutions, organize a street protest, or take any other adequate measure

- Form a working group composed by everyone involved in social health work in 23 de Enero through the health committees, as well as the communal councils

- The leadership of the health group should rotate among members

The security roundtable

- Maintain security over the area

- Co-ordinate the security issue with the colectivos and the social groups in the area

- Make sure that the keys are handed over to the security group

- Improve the illumination in the area around the CDI

- Make a daily diary over occurrences around the CDI structure

- Prohibit the sale of liquor in the surrounding area

- Promote the sale of fast food instead of liquor

- Prohibit cars stationing in front of the area leading into the CDI

- Exercise territorial control together with the communal councils

- Make an inventory of everything that is inside and around the CDI building

- Make a telephone directory of everyone who will be involved in the security issue

- Improve the fence around the CDI building

The sports roundtable

- Make sure that both the football and the baseball fields are restored according to a detailed list of repairs

The social comptrollership roundtable

- Constitute a social comptrollership named Network of Social Comptrollerships Simón Bolívar (Red the Contraloría Social Simón Bolivar) composed by the four communal councils that directly border the area, by other nearby communities, by the metropolitan council representative for the parish and the local contact person (enlace parroquial) in 23 de Enero for the Libertador Municipality

- Divide the work between different work brigades

- Make an archive of all documents and document everything that has to do with institutional logistics as well as logistics in the neighborhood

- Demand immediate results from the institutions involved

- Work with everyone in a unified manner (forma mancomunada)

When all the roundtables had presented their findings, the community voted for the suggestions of each group-all of them were approved. This was then duly noted in the acta (minutes) of the event. All participants signed, thereby giving the decisions made in the assembly an appearance 
of public legitimacy. Overall, the meeting proceeded in a rather harmonious manner, and the problematic involvement of the colectivos seemed to have been forgotten. It was Felipe who ended the meeting this time. He gave a lengthy speech during which he promised to contact Electricidad de Caracas and invite them to join the initiative and put up more light posts in the area. Moreover, he wanted everyone to notice how much could be achieved if the community and the institutions moved in the same direction:

In August 2009 we will have been struggling for this CDI for three years, for it to be finished. First we observed that the construction was done wrongly, then we denounced that those who were carrying out the work weren't qualified for the job, we denounced the work inspector because he never appeared and when he did appear he just met with a little group and didn't give any answers to the community.

So we were denouncing all this, and today we see the result. What is it that we want to say with this? That through the interaction between the institutions and the communities we can recuperate our spaces; I don't have to go to Globovisión nor to Radio Caracas Televisión and complain in order to make things happen, because el camerada Oscar, el camerada Walter, my own person because I am a public functionary elected by popular vote, ${ }^{11}$ we have the obligation to support the communities, and there is another example, Gerardo that got involved today, and the other compañera as well, this is our mission and our function, we are here in order to give the communities all the necessary tools to solve their problems. And why? Because we have a leader, a leader who is giving us lineas (directions) every day, a leader that every day tells us what we need to do, and I believe....

Which is our obligation? Comply with this mandate. Why mandates? Because it is the welfare of our communities that we are fighting for. And who will bring you welfare? People from other sectors? No, it has to be us, what has happened here with this CDI really should not happen here again in 23 de Enero, it is really shameful that it happened here ... but it happened and it has given us the opportunities to have here with us the compañeros from (the Ministry) of Health, Fundacaracas, Parlamento Latino and all the other entities that have come here and that have been preoccupied with these problems ... but we will certainly move forward shortly, in accordance with the procedures that will be outlined by INAVI, I will make a promise on behalf of camerada Walter, that he will accompany me in this, Walter is a deputy in the Parlamento Latinoamericano, a neighbor from Catia, friends for all our lives, and I will publicly make this promise on behalf of him that he will accompany me doing all these procedures so that this has a happy ending. 
The meeting ended in general enthusiasm, after all had agreed that, those who could, would assist in doing the inventory of what was left of the CDI the next day.

Over the next few weeks, several meetings took place. A jornada de trabajo communitario (community work day) was arranged for a Sunday morning in order to clean up sand and dirt from the inside of the CDI. The colectivo La Piedrita had mobilized their youth group, a group of boys around 15 or 16 years old, whose members were giggling and whispering at the sight of the gringa ethnographer that was moving sand and dirty water out of the building. A group of people from the nearby communal councils also participated and, as frequently happens, they were mostly women. A Cuban team of doctors was expected later that week to inspect the site, but they had to travel to the city of Maracay, two hours from Caracas, because of a hospital building that had suffered damage during an earthquake. (Several minor earthquakes were recorded in the coastal region that spring.) The meeting was postponed to a few days later when Felipe, Oscar, a few other people from the community and I gathered. There were also two representatives from the Cuban commission in Miraflores, one engineer and the female doctor at the head of all the Cuban doctors stationed in Caracas, a representative from the company that had been contracted to repair the CDI, and a representative from the municipality. They had brought detailed drawings of the building with them, and were discussing the next steps with Oscar and Felipe, who were both extremely happy with the involvement of high-level figures. The CDI module had apparently been put on a high-priority development list by Fundacaracas. Oscar and Felipe were both duly filming the whole meeting and made everyone present sign the minutes of the meeting.

After the meeting, I spoke with Oscar and Felipe for a while. They told me that the real issue now lay with the health committee. The health committee would have considerable influence over who would be employed at the hospital (nurses, assistants, janitors and so on), once it was up and running. According to the philosophy of community development, the community was supposed to have control over these matters. In the case of construction projects, this was also a way to stop labor unions from exercising their mafia-like influence over employment decisions, or from paralyzing work, if they so wished. Thus, the employment issue stirred the community and generated quite a bit of maneuvering by those who wanted control over any hiring process. The person running the show, I soon understood, was 
once again Señora Yurelia, the lady with the baseball field and "interests," who had quite a lot of influence on the committee connected to the Barrio Adentro I health module, in front of the CDI.

\section{TOWARD THE END}

Suddenly, activities waned down. Easter was coming, and Venezuelans cherish that holiday for traveling. Many people "add on" an extra few days to the vacation, which means that everything stops both in the communities and in public institutions during the holidays, and it takes a long time before things go back to normal. Felipe and Oscar were busy organizing the traditional Easter event in their community - a march simulating the suffering of Christ on the Via Dolorosa and his death on the cross. An actor draped in white, portraying Jesus, carried a cross through the community, and people followed him in his long march. When we reached one of the chapels in 23 de Enero, a group of "soldiers" was bashing and beating him before the march resumed, up to the football stadium and outside the bloque where Felipe and Oscar lived. There he was "hung" on a large wooden cross.

Because of sudden health issues, Oscar had very little time on his hands after the Easter holiday. Thus, despite being the motor of the project, he pulled out. When I asked him, he said that the initiative had to be taken over by the community living near the CDI. He was tired of trying to move the project along. Now people in the community had to take over. Not too long after that, I returned to Norway.

\section{The End of The STORY}

When I returned, half a year later, work around the CDI was once again paralyzed. I asked Sergio, a friend from the community next to the football field, why, and he answered that they had just reconvened to get the work started once more. I tried to inquire into why the project had stopped, but he said that he didn't know. "When these things happen, it is often sabotage," he said. Perhaps the money had dried up because of the fall in oil prices that autumn, he speculated. Or perhaps it had been postponed because there had been a change in the municipal government. "The real reason for why it stopped is not known; a lot of things are being said" (se dice muchas cosas).

When I went back the following year, the CDI was finished and up and running. Sergio told me that it had been completed with money 
coming from the presidency. Someone else told me that it had been finished with money from the Ministry of Popular Power for Health. Then I asked Oscar, who had practically retired from community politics for the time being because of his personal health problems. He puffed a bit and said that the woman who controlled the baseball field had basically taken over and had been running the show. "She is a malandra (thug/bully)," he said. Besides, she had two sons who were bullying and intimidating people who dared to challenge her influence on the community. Thus, at the end of the day, she had placed her people to work in the hospital. The doctors were a mix of Cubans and Venezuelans who were "more or less attending people," according to Oscar. He had just pulled out of the process altogether: "We didn't want to exhaust ourselves there, people didn't participate. And it is difficult when you don't live exactly there in the area. It is not enough to be there every 15-20 days; you have to be there all the time to accompany people." He also said that the colectivos had stopped being involved after the first phase when they were safeguarding the security situation in the building area. "She is there with her people," Oscar repeated. "She has a lot of influence in that community."

It was difficult for me to tell whether Oscar was critical of how the hospital was working because he was still hurt for losing control over the process or there were real issues at the CDI. A woman, who had been involved in the project from the very start, told me that everything was going fine over there, that the colectivos had "pulled out" after the construction phase and that the health committees were working closely with the hospital. "Everything was going fine," she said, and people were being attended.

In October 2013, while back in Norway, I read in the online version of the daily Caracas newspaper, Correo del Orinoco, that the football field had just been finished by Fundacaracas. The field, which was now at the disposal of local children and youths, featured artificial grass and met the standards for regulation fields. It had wardrobes, toilets, and illumination for late-night use. The mayor of the Libertador Municipality, Jorge Rodriguez; the head of the capital district (Distrito Capital), Jacqueline Farías; and parish authorities were invited to inspect the football field together with the local communities. In his speech, Jorge Rodriguez said that "this is not about finally finishing the building of the field, this is just the beginning, the beginning for the football players for the future that will be formed here, the golden generation that Chávez granted us" (Correo del Orinoco 2013). 


\section{Community Action and the Politics of Space}

This chapter has illustrated the inherent challenges that popular neighborhood groups face when trying to constitute themselves as collective political subjects (Lazar 2008:58) in the context of community politics. The experiences of popular mobilization since Chávez was first elected served to create different, and sometimes competing, bases of power in the community, which in many cases clashed with one another. This was particularly the case in the parish of 23 de Enero, where the previous territorial dominance of the colectivos was partly displaced by the establishment of the communal councils. This feature was however not unique to 23 de Enero. The process of "forging a community" was an issue present in all arenas of struggle. In order to make their claims toward the state, communities were trying to present themselves as a unified political body (either as one single communal council, or as an association of several community groups, as in the case described), while, at the same time, facing internal conflicts.

As we saw in the CDI case study, the ideal of a unified, collective body of citizens, constituting itself as a community vis-á-vis the state, was clearly shaken by the de facto heterogeneity between different interests and priorities as well as positions of power and influence. Both the people with rat problems and the people with drainage problems, referenced "their community" when speaking of their damages they had all suffered, and of the right they all had to see their problems resolved. Colectivos of various kinds were constantly trying to portray themselves as "community"-in this context as safeguarders of the common interests of the whole community, and under-communicating their special and controversial status in the parish. At the same time, they tried to portray themselves as special groups selflessly attending the interests of the community in matters of public security. Oscar and Felipe on the other hand (who had little personal interests in the project besides local prestige and a desire to improve local health facilities ${ }^{12}$ ) were constantly trying to frame everything in a wider context of collective social struggle and poder popular.

Señora Yurelia, "the lady with the interests" appeared to be the winner in the end. She was tied to the Barrio Adentro health module and led the sports committee in her communal council, controlling the local baseball field: positions that gave her significant leverage in her community. Moreover, she had the advantage of spatial proximity to the site and appeared to be connected to other power bases in the community, like the local council woman.

Oscar and Felipe on the other hand, who were the ones who had initiated the process and managed to engage public and political entities, 
might have seemed like the individuals who could have gained the most recognition and influence over the process. However, the fact that they lived elsewhere (approximately $1 \mathrm{~km}$ away) provided them with a weaker claim to represent local interests and less chances of ganarse los espacios (gain the spaces) through close interaction with local residents. This illustrates the symbolic importance given to space, as well as how community politics and the politics of local recognition are closely tied to a personal relationship with the space-confirmed by the need to be present, visible and ganarse los espacios.

What this case showed is thus the multi-faceted notion of community as it is used in Bolivarian political discourse. Community is a context-specific self-explanatory concept as well as an ambivalent concept that can be used strategically in order to substantiate claims to legitimacy both within the community and toward the state. In spite of the local conflicts simmering below the surface, people were capable of calling upon the notion of community in order to make their claims toward the state representatives. Their claim to represent the health interests of 23 de Enero (and other parishes as well, indeed the whole pueblo, as Felipe said) alluded to the government policies of paying up a social debt to poor communities. They could therefore draw on a broader conundrum of political discourses and symbolism when they staked out a position for themselves as the legitimate protagonists of bringing this process forward. All along, in the conversation with public representatives, they underscored their prerogative not only to participate in the planning process, but also to have a final say in how it would proceed. Similarly, the state representatives explicitly recognized the crowd and its inherent collective political qualities, attributing them not only with the right to make claims toward the state in the name of "the community" as a whole, but also with the right to participate in the process itself.

However, as this example and subsequent discussions will show, "the community" had few chances of actually enforcing its legally sanctioned right to influence and shape public policy. The CDI project was probably delayed for reasons far beyond the community's reach. There was a change in municipal administration at the time, which implies that the majority of institutional personnel are changed (see Chap. 10) as well as an overhaul of municipal budget. This illustrates the fragility of community-initiated politics, an issue that will be further discussed in the following chapter where we will explore the insides of the Venezuelan state. 


\section{Notes}

1. "The community" is a contentious concept in scholarly writing (e.g., see Cohen 1985), and some scholars have suggested that the concept should be abandoned altogether (Young 1986 in Creed 2004:57). However, in spite of its ambiguity, "community" will inevitably be used in this discussion. Not only is it a concept that is frequently used in local discourse, but it is also the concept that best encompasses the social setting that we are trying to get a grasp on. However, I am not presupposing that it is possible to understand a "community" a priori, or that the emic usage of the word presupposes a coherent or stable idea of what a "community" is.

2. This was passed as a law in 2006, with the title Ley Especial de Regularización Integral de la Tenencia de la Tierra en los Asentamientos Urbanos Populares (Special Law for Integral Regulation and Land Tenure in Urban Popular Settlements).

3. According to Article 2 of the Law for the Communal Councils: "The Communal Councils, within the constitutional framework of a participative and protagonistic democracy, are instances of participation, articulation and integration between the citizens and the various community organizations, social and popular movements, which allow the organized people to exercise [as a] communitarian government and [the direct exercise of] public policy and projects oriented towards responding to the communities' necessities, potentials and aspirations in the construction of the new model of a socialist society of equality, equity and social justice." Author's translation from Spanish. The full law text can be found at http://www.minci.gob.ve/2012/09/ley-organica-de-los-consejoscomunales/.

4. These are the executive committee (unidad ejecutiva), the communitarian financial and administrative unit (unidad administrativa y financiera comunitaria), and the unit for social comptrollership (unidad de contraloría social).

5. The five motors are la Ley Habilitante (the enabling law), to grant the president the power to enact radical reforms; la Reforma Constitucional Socialista (the Socialist constitutional reform), which Chávez lost narrowly in 2007; la Educación Popular (popular education), an educational program that teaches Socialist, anti-imperialist and anti-colonialist values; la Nueva Geometría del Poder (the new geometry of power), which radically changes territorial and administrative structures in order to facilitate social and political development in an endogenous manner; and el Poder Comunal (the communal power), making popular power a backbone of the affairs of the state, through communal councils, communes and so on. 
6. However, the constitutional base is legitimized in paragraph 70 (GarcíaGuadilla 2008:8), which states that "Participation and involvement of people in the exercise of their sovereignty in political affairs can be manifested by: voting to fill public offices, referendum, consultation of public opinion, mandate revocation, legislative, constitutional and constituent initiative, open forums and meetings of citizens whose decisions shall be binding among others; and in social and economic affairs: citizen service organs, selfmanagement, co-management, cooperatives in all forms, including those of a financial nature, savings funds, community enterprises, and other forms of association guided by the values of mutual cooperation and solidarity. The law shall establish conditions for the effective, functioning of the means of participation provided for under the present article." See Constitution of the Bolivarian Republic of Venezuela (1999).

7. Now called Ministerio del Poder Popular para la Comuna y los Movimientos Sociales.

8. All costs associated with the stay at Cuba are paid by the agreement, including for a relative to accompany the patient.

9. Manuel Rosales was the former governor of Zulia who lost the presidential elections in 2007, and who fled to Peru seeking political asylum after he was charged for extensive corruption during his time as a governor.

10. Here clarification is needed. Chávez set up a special unit linked directly to the president's office where people could come and complain about problems they may have with the public institutions. The president's office then called up the relevant institutions and commanded them to resolve the problem. The office was located in the White House, an impressive palace building guarded by the presidential army vis-à-vis the presidential palace Miraflores. Anyone could line up in the queue and have their complaint registered, and people came from all over the country to do so.

11. Felipe held an elected position in the local circuit of PSUV.

12. I can say this because I came to know both of them very well over time.

\section{BiBLIOGRAPHY}

Aguiar, Asdrúbal. 2007. Los cinco motores de la Revolución en Venezuela. Analitica. http://www.analitica.com/opinion/opinion-nacional/los-cincomotores-de-la-revolucion-en-venezuela/. Accessed February 20, 2017.

Alvarez, Rosángel, and María Pilar García-Guadilla. 2011. Controlaría social y clientelismo: La praxis de los consejos comunales en Venezuela. Politeia 34 (46): 175-207.

Auyero, Javier. 2001. Poor People's Politics. Peronist Survival Networks and the Legacy of Evita. Durham and London: Duke University Press. 
Brouwer, Steve. 2011. Revolutionary Doctors. How Venezuela and Cuba Are Changing the World's Conception of Health Care. New York: Monthly Review Press.

Ciccariello-Maher, George. 2013. We Created Chávez: A People's History of the Venezuelan Revolution. Durham and London: Duke University Press.

- 2016. Building the Commune. Radical Democracy in Venezuela. London and New York: Verso.

Cohen, Anthony. 1985. The Symbolic Construction of Community. London and New York: Routledge.

Constitution of the Bolivarian Republic of Venezuela. 1999. Article 70. http:// www.venezuelaemb.or.kr/english/ConstitutionoftheBolivarianingles.pdf. Accessed February 20, 2017.

Correo del Orinoco. 2013. Sierra Maestra tiene su estadio de fútbol. Correo del Orinoco, October 21. http://www.ciudadccs.info/?p=491568. Accessed December 20, 2013.

Creed, Gerald. 2004. Constituted through Conflict: Images of Community (and Nation) in Bulgarian Rural Ritual. American Anthropologist 106 (1):56-70.

D'Elia, Yolanda, and Luis Francisco Cabezas. 2008. Las Misiones Sociales en Venezuela. Caracas: Instituto Latinoamericano de Investigaciones Sociales (ILDIS).

Duno-Gottberg, Luis. 2009. Social Images of Anti-Apocalypse: Bikers and the Representation of Popular Politics in Venezuela. Contracorriente 6 (2): 144-172.

García-Guadilla, María Pilar. 2007. Ciudadanía y autonomía en las organizaciones sociales bolivarianas: Los Comités de Tierra Urbana como movimientos sociales. Cuadernos de Cendes 24 (66): 47-73.

- 2008. Poder popular y límites de democracia participativa en Venezuela: la experiencia de los Consejos Comunales. Paper delivered at the II Conferencia of the Venezuela Section of Latin American Studies Association (LASA), Caracas, May 2008.

Gledhill, John. 1994. Power and Its Disguises. Anthropological Perspectives on Politics. London: Pluto Press.

Goffman, Erving. 1956. The Presentation of Self in Everyday Life. New York: Doubleday.

Hawkins, Kirk, Guillermo Rosas, and Michel E. Johnson. 2011. The Misiones of the Chávez Government. In Venezuela's Bolivarian Democracy. Participation, Politics and Culture under Chávez, ed. D. Smilde and D. Hellinger. Durham and London: Duke University Press.

Lazar, Sian. 2008. El Alto, Rebel City. Self and Citizenship in Andean Bolivia. Durham and London: Duke University Press.

Martinez, Carlos, Michael Fox, and Jojo Farell. 2010. Venezuela Speaks! Voices from the Grassroots. Oakland: PM Press.

Maya, Margarita López. 2011. Hacia el socialismo del siglo XXI: Los consejos comunales, sus cambios conceptuales y las percepciones de los participantes en Caracas. In Ciudadania y Legitimidad Democrática en América Latina, ed. I. Cheresky. Buenos Aires: Prometeo. 
Moreno, Marco Aponte. 2008. Metaphors in Hugo Chávez Political Discourse: Conceptualizing Nation, Revolution, and Opposition. PhD dissertation, Graduate Faculty in Hispanic and Luso-Brazilian, City University of New York.

Nichols, Elizabeth Gackstetter, and Kimberley J. Morse. 2010. Venezuela. Santa Barbara, California, Denver, Colorado and Oxford, England: ABC-CLIO.

Nuijten, Monique. 2003. Power, Community, and the State. The Political Anthropology of Organization in Mexico. London and Sterling, VA: Pluto Press.

Républica Bolivariana de Venezuela. 2007. Proyecto Nacional Simón Bolivar 2007-2013. http://www.psuv.org.ve/wp-content/uploads/2011/03/ProyectoNacionalSim\%C3\%B3n-Bol\%C3\%ADvar.pdf. Accessed February 20, 2017.

Strønen, Iselin Åsedotter. 2006. "For Us This Is Utopia Coming True.” Venezuela's Bolivarian Revolution and Popular Movements in a Caracas Barrio. MA thesis, Department for Social Anthropology, University of Bergen.

- 2012. Development from Below and Oil Money from Above: Popular Organization in Contemporary Venezuela. In Flammable Society. Studies on the Socio-economics of Oil and Gas, ed. J.-A. McNeish and O. Logan. London: Pluto Press.

Valencia, Cristobal. 2015. We Are the State! Barrio Activism in Venezuela's Bolivarian Revolution. Tucson: The University of Arizona Press.

Velasco, Alejandro. 2015. Urban Popular Politics and the Making of Modern Venezuela. Oakland: University of California Press.

Wilpert, Gregory. 2011. Venezuela's Experiment in Participatory Democracy. In The Revolution in Venezuela. Social and Political Change under Chávez, ed. T. Ponniah and J. Eastwood. Cambridge, MA: David Rockefeller Center for Latin American Studies, Harvard University.

Ystanes, Margit. 2011. Precarious Trust. Problems of Managing Self and Sociality in Guatemala. PhD dissertation, Department of Anthropology, University of Bergen.

Open Access This chapter is distributed under the terms of the Creative Commons Attribution 4.0 International License (http://creativecommons.org/ licenses/by/4.0/), which permits use, duplication, adaptation, distribution and reproduction in any medium or format, as long as you give appropriate credit to the original author(s) and the source, provide a link to the Creative Commons license and indicate if changes were made.

The images or other third party material in this chapter are included in the chapter's Creative Commons license, unless indicated otherwise in a credit line to the material. If material is not included in the chapter's Creative Commons license and your intended use is not permitted by statutory regulation or exceeds the permitted use, you will need to obtain permission directly from the copyright holder.

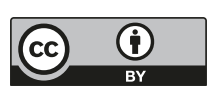

